\title{
Karakteristik Ketebalan Makula Sentral Sebelum dan Sesudah Injeksi Intravitreal Bevacizumab di RSKM Padang Eye Center Periode Januari 2018 - Januari 2019
}

\author{
Ashan, $\mathrm{H}$ \\ Bagian Mata Fakultas Kedokteran Universitas Baiturrahmah, Padang, Indonesia \\ e-mail : havesashan@gmail.com \\ Bagian Mata Rumah Sakit Khusus Mata Padang Eye Center, Padang, Indonesia
}

\begin{abstract}
Abstrak
Latar belakang: Edema makula merupakan penyebab umum terjadinya penurunan tajam penglihatan. Akumulasi cairan di dalam retina dan peningkatan ketebalan retina menyebabkan rusaknya blood retinal barrier. Injeksi intravitreal anti-VEGF (bevacizumab) bertujuan untuk mengurangi aktivitas VEGF, dimana oklusi vena pada retina (Retinal Vein Occlusion/ RVO) menginduksi peningkatan kadar VEGF yang menyebabkan peningkatan permeabilitas vaskular dan menimbulkan edema makula. Tujuan: Mengetahui ketebalan makula sentral sebelum dan sesudah injeksi intravitreal bevacizumab pada pasien oklusi vena retina sentral dan oklusi vena retina cabang melalui pengamatan hasil pemeriksaan OCT (Optical Coherence Tomography). Metode: Penelitian ini merupakan penelitian deskriptif retrospektif berdasarkan hasil penelusuran rekam medis terhadap 8 pasien RVO di RSKM Padang Eye Center periode Januari 2018 sampai Januari 2019. Penelitian dilakukan pada bulan Maret hingga April 2020. Hasil: Subyek penelitian sebanyak 8 orang (8 mata) terdiri dari 2 laki-laki $(25,0 \%)$ dan 6 perempuan $(75,0 \%)$. Rentang usia berkisar antara 41-80 tahun. Ketebalan makula sentral saat awal didapatkan mayoritas $>300 \mu \mathrm{m}$ yaitu sebanyak 7 orang $(87,5 \%)$, sedangkan $\leq 300 \mu \mathrm{m}$ sebanyak 1 orang $(12,5 \%)$. Satu bulan pasca injeksi didapatkan mayoritas ketebalan makula sentral $\leq 300 \mu \mathrm{m}$ sebanyak 5 orang $(62,5 \%)$, sedangkan $>300 \mu \mathrm{m}$ yaitu sebanyak 3 orang $(37,5 \%)$. semua pasien mengalami penurunan ketebalan makula sentral yaitu sebanyak 8 subjek (100\%). Kesimpulan: Semua pasien mengalami penurunan ketebalan makula sentral 1 bulan pasca injeksi intravitreal bevacizumab.
\end{abstract}

Katakunci : edem makula, OCT, Oklusi Vena Retina, RVO.

\begin{abstract}
Background: Macular edema is a common cause of vision disturbing. Fluid accumulation in the retina and increased thickness of the retina cause damage to the blood retinal barrier. Intravitreal anti-VEGF (bevacizumab) injection aims to reduce VEGF activity, where retinal vein occlusion $(R V O)$ induces an increase in VEGF levels which causes an increase in vascular permeability and results in macular edema. Objective: To determine the central macular thickness before and after intravitreal injection of bevacizumab in patients with central retinal vein occlusion and branch retinal vein occlusion through observing the results of OCT (Optical Coherence Tomography) examination. Method: This research is a retrospective descriptive study based on the results of medical records tracing of 8 RVO patients in the Padang Eye Center Hospital for the period January 2018 to January 2019. The study was conducted in March to April 2020. Result: The study subjects consisted of 8 people (8 eyes) consisting of 2 men (25.0\%) and 6 women (75.0\%). The age range ranges from 41-80 years. The thickness of the central macula at the start was found to be majority > $300 \mu \mathrm{m}$, as many as 7 people $(87.5 \%)$, while $\leq 300 \mu \mathrm{m}$ was 1 person $(12.5 \%)$. One month after injection found the majority of central macular thickness $\leq 300 \mu \mathrm{m}$ by 5 people (62.5\%), while> $300 \mu \mathrm{m}$ is as many as 3 people (37.5\%). All patients experienced a decrease in central macular thickness in 8 subjects (100\%). Conclusion: All patients experienced a decrease in central macular thickness 1 month after intravitreal injection of bevacizumab.
\end{abstract}

Keywords : macular edema, OCT, Retinal Vein Occlusion, RVO.

Health \& Medical Journal 


\section{Pendahuluan}

Pola hidup yang tidak sehat seperti diet yang tidak seimbang, kurangnya berolah raga dan faktor usia dapat meningkatkan resiko terjadinya penyakit antara lain hipertensi, hiperlipidemia dan diabetes. Penyakit tersebut dapat menyebabkan oklusi vena pada retina diantaranya Branch Retinal Vein Occlusio (BRVO) dan Central Retinal Vein Occlusio (CRVO). BRVO terjadi sekitar 80 $\%$, namun CRVO merupakan penyebab kehilangan penglihatan yang signifikan dibandingkan BRVO. ${ }^{1-5}$

Oklusi vena retina atau Retinal Vein Occlusion (RVO) merupakan penyakit pembuluh darah retina terbanyak kedua setelah retinopati diabetikum. RVO terbagi menjadi 2 klasifikasi tergantung dari lokasi oklusinya yaitu BRVO dan CRVO. Faktor penyebab timbulnya RVO didasari oleh berbagai macam kondisi patologis sistemik maupun lokal. ${ }^{1,2,6}$

Oklusi vena retina sentralis lebih sering terjadi pada usia tua $(90 \%$ terjadi pada usia $>50$ tahun), walaupun pernah dilaporkan terjadi pada usia yang lebih muda, dengan perbandingan laki-laki sama dengan wanita. Bertambahnya usia dan faktor penyerta kardiovaskular seperti hipertensi, hiperlipidemia dan diabetes melitus merupakan faktor resiko sistemik penyebab oklusi vena retina sentralis yang paling sering. Perubahan dalam viskositas darah (seperti anemia dan leukemia), glaukoma sudut terbuka dan pemakaian kontrasepsi oral, turut berperan dalam terjadinya faktor resiko oklusi vena retina sentral., ${ }^{1,2,6}$

Edema makula merupakan penyebab umum terjadinya penurunan tajam penglihatan. Akumulasi cairan di dalam retina dan peningkatan ketebalan retina menyebabkan rusaknya blood retinal barrier. Edema makula merupakan penyebab utama terjadinya penurunan tajam penglihatan pada pasien oklusi vena retina. ${ }^{1-6}$
Tatalaksana oklusi vena adalah dengan mengembalikan perfusi jaringan retina, mengatasi faktor predisposisi dan mencegah komplikasi lebih lanjut berupa edema makula kronik dan sikatrik pada makula, dengan cara mengurangi faktor-faktor resiko seperti mengatasi hipertensi, hiperlipidemia, pemberian antikoagulan dan mengurangi viskositas darah. Terapi bedah adalah dengan injeksi anti-VEGF intravitreal. Injeksi intravitreal anti-VEGF bertujuan untuk mengurangi aktivitas VEGF dimana oklusi vaskular menginduksi peningkatan kadar VEGF yang menyebabkan peningkatan permeabilitas vaskular dan menimbulkan edema makula. ${ }^{1-5,7}$

Pemberian anti-VEGF pada pasien oklusi vena retina sentral maupun cabang dapat mengurangi edema makula dengan menurunkan ketebalan makula sentral. Pengetahuan mengenai karakteristik demografis, klinis serta angka keberhasilan pasca injeksi intravitreal bevacizumab pasien oklusi vena diharapkan dapat membantu dalam pemilihan tindakan yang tepat, sekaligus memberikan prediksi kesuksesan pasca injeksi di masa mendatang.

Berdasarkan uraian diatas penulis tertarik untuk mengetahui ketebalan makula sentral sebelum dan sesudah injeksi intravitreal bevacizumab pada pasien oklusi vena retina sentral dan oklusi vena retina cabang di RSKM Padang Eye Center pada bulan Januari 2018 - Januari 2019.

Tujuan penelitian adalah mengetahui karakteristik pasien oklusi vena retina sentral dan oklusi vena retina dan untuk mengetahui keberhasilan pasca injeksi intravitreal bevacizumab pada pasien oklusi vena retina sentral dan oklusi vena retina cabang.

\section{Metode Penelitian}

Sampel penelitian adalah pasien oklusi vena retina sentral dan oklusi vena retina cabang di divisi vitreoretina yang menjalani injeksi 
intravitreal bevacizumab di RSKM Padang Eye Center bulan Januari 2018 - Januari 2019. Kriteria inklusi adalah seluruh data pasien oklusi vena retina sentral dan oklusi vena retina cabang yang menjalani injeksi intravitreal bevacizumab. Kriteria eksklusi adalah data pasien yang tidak lengkap, data pasien yang tidak kontrol serta rekam medis yang tidak dapat ditelusuri.

Desain penelitian adalah deskriptif retrospektif berdasarkan hasil penelusuran rekam medis. Tempat penelitian yaitu di RSKM Padang Eye Center. Waktu dan sampel penelitian diambil dari rekam medis periode Januari 2018 - Januari 2019. Jenis data yang digunakan adalah data sekunder yang berasal dari rekam medis subjek dengan alur pengumpulan data sebagai berikut :

1. Peneliti melihat catatan laporan injeksi intravitreal anti-VEGF periode Januari 2018- Januari 2019.

2. Peneliti mencari nama, nomor rekam medis semua pasien yang tercatat dari sumber tersebut.

3. Pasien yang memenuhi kriteria inklusi, selanjutnya dicatat nama dan nomor rekam medisnya, kemudian dilakukan pencarian rekam medis di ruang rekam medis.

4. Data dari status rekam medis yang berhasil dikumpulkan, kemudian dicatat dalam tabel induk penelitian.

5. Variabel yang dinilai adalah Data demografis mencakup usia, jenis kelamin, dan data klinis mencakup lateralitas, diagnosis, ketebalan makula sentral sebelum dan sesudah injeksi.

\section{HASIL}

Berdasarkan penelusuran data rekam medis didapatkan 14 pasien oklusi vena retina yang menjalani injeksi intravitreal bevacizumab di RSKM PEC pada periode Januari 2018 hingga Januari 2019. Sebanyak 6 subjek dieksklusi karena data rekam medis mengenai hasil OCT makula satu bulan pasca injeksi tidak ada, pasien tidak kontrol ulang, tidak dilakukan pemeriksaan OCT setelah 1 bulan injeksi maupun rekam medis yang tidak dapat ditelusuri. Jumlah data rekam medis yang dapat diolah menjadi sampel penelitian sebanyak 8 subjek.

\section{A. Karakteristik Umum Subjek Penelitian}

Karakteristik umum subjek penelitian dapat dilihat pada Tabel 1.

Tabel 1. Karakteristik Pasien OKLusi Vena RETINA YANG MENJALANI INJEKSI INTRAVITREAL BEVACIZUMAB

\begin{tabular}{lcc}
\hline \multicolumn{1}{c}{ Karakteristik } & Jumlah & Persentase (\%) \\
\hline Jenis Kelamin & & \\
- Laki-laki & 2 & 25 \\
- Perempuan & 6 & 75 \\
Usia & & \\
- $41-50$ tahun & 1 & 12,5 \\
- $51-60$ tahun & 4 & 50,0 \\
- $61-70$ tahun & 0 & 0 \\
- $71-80$ tahun & 3 & 37,5 \\
\hline
\end{tabular}

Tabel 1. menunjukkan dari 8 subjek penelitian terdapat sebanyak 2 orang $(25,0 \%)$ berjenis kelamin laki-laki dan 6 orang $(75 \%)$ berjenis kelamin perempuan. Pasien memiliki rentang usia 51-60 tahun (50\%), $71-80$ tahun $(37,5 \%), 41-50$ tahun $(12,5 \%)$ dan 61-70 tahun (0\%).

\section{B. Karakteristik Klinis Subjek Penelitian}

Karakteristik klinis subjek penelitian dapat dilihat pada Tabel 2.

Tabel 2. Karakteristik Klinis SubJek Penelitian

\begin{tabular}{|c|c|c|}
\hline Karakteristik & Jumlah & Presentase (\%) \\
\hline \multicolumn{3}{|l|}{ Diagnosis } \\
\hline - BRVO & 5 & 62,5 \\
\hline - $\quad$ CRVO & 3 & 37,5 \\
\hline \multicolumn{3}{|l|}{ Lateralitas } \\
\hline - Mata kanan & 5 & 62,5 \\
\hline - Mata kiri & 3 & 37,5 \\
\hline \multicolumn{3}{|l|}{ Ketebalan Makula } \\
\hline \multicolumn{3}{|l|}{ Sentral Awal } \\
\hline - $\quad \leq 300 \mu \mathrm{m}$ & 1 & 12,5 \\
\hline - $\quad>300 \mu \mathrm{m}$ & 7 & 87,5 \\
\hline Ketebalan Makula & & \\
\hline
\end{tabular}


Sentral 1 Bulan

Pasca Injeksi

- $\quad \leq 300 \mu \mathrm{m}$

- $\quad>300 \mu \mathrm{m}$

Tabel 2. menunjukkan pasien dengan diagnosis CRVO sebanyak 3 orang $(37,5 \%)$ sedangkan BRVO sebanyak 5 orang $(62,5 \%)$. Lateralitas terbanyak didapatkan pada mata kanan yaitu 5 orang $(62,5 \%)$. Ketebalan makula sentral saat awal $>300 \mu \mathrm{m}$ yaitu sebanyak 7 orang $(87,5 \%)$, sedangkan $\leq 300 \mu \mathrm{m}$ sebanyak 1 orang $(12,5 \%)$. Satu bulan pasca injeksi didapatkan ketebalan makula sentral $\leq 300 \mu \mathrm{m}$ sebanyak 5 orang $(62,5 \%)$, sedangkan $>300 \mu \mathrm{m}$ sebanyak 3 orang $(37,5 \%)$.

Karakteristik klinis subjek penelitian sebelum dan satu bulan sesudah injeksi intravitreal bevacizumab dapat dilihat pada Tabel 3.

TABEL 3. Karakteristik Klinis SubJEK Penelitian Sebelum dan Satu Bulan Sesudah INJEKSI INTRAVITREAL BEVACIZUMAB

\begin{tabular}{ccccccc}
\hline $\begin{array}{c}\text { No. } \\
\text { Subjek Kela } \\
\begin{array}{c}\text { Min } \\
\text { M/P) }\end{array}\end{array}$ & $\begin{array}{c}\text { Usia } \\
\text { (tahun) }\end{array}$ & $\begin{array}{c}\text { Diag } \\
\text { nosis }\end{array}$ & $\begin{array}{c}\text { Latera } \\
\text { litas }\end{array}$ & $\begin{array}{c}\text { CMT CMT 1 } \\
\text { Awal } \\
(\boldsymbol{\mu m})\end{array}$ & $\begin{array}{c}\text { Bulan } \\
\text { Pasca } \\
\text { Injeksi } \\
(\boldsymbol{\mu m})\end{array}$ \\
\hline 1 & P & 71 & CRVO & Kanan & 305 & 240 \\
2 & P & 73 & CRVO & Kiri & 394 & 281 \\
3 & P & 71 & CRVO & Kanan & 284 & 250 \\
4 & P & 56 & BRVO & Kanan & 523 & 394 \\
5 & L & 58 & BRVO & Kanan & 377 & 269 \\
6 & P & 49 & BRVO & Kiri & 427 & 331 \\
7 & P & 58 & BRVO & Kanan & 404 & 291 \\
8 & L & 60 & BRVO & Kiri & 407 & 320 \\
\hline
\end{tabular}

Tabel 3. menunjukkan semua pasien mengalami penuruan CMT setelah dilakukan injeksi intravitreal bevacizumab.

\section{Karakteristik Penurunan Ketebalan Makula Sentral}

Karakteristik penurunan ketebalan makula sentral satu bulan setelah injeksi dapat dilihat pada Tabel 4.
Tabel 4. Karakteristik Penurunan Ketebalan MAKUla SENTRAL

\begin{tabular}{|c|c|c|}
\hline Karakteristik & Jumlah & $\begin{array}{c}\text { Presentase } \\
(\%)\end{array}$ \\
\hline $\begin{array}{l}\text { Perubahan Ketebalan } \\
\text { Makula Sentral } \\
\text { - Penurunan CMT } \\
\text { - CMT tetap atau } \\
\text { meningkat }\end{array}$ & 8 & 100 \\
\hline
\end{tabular}

Tabel 4. menunjukkan semua pasien mengalami penurunan ketebalan makula sentral yaitu sebanyak 8 subjek $(100 \%)$ yang didapatkan melalui metode konsekutif sampling pada setiap mata pasien.

\section{Pembahasan}

Mayoritas pasien memiliki rentang usia 5160 tahun $(50,0 \%)$ dan 71-80 tahun $(37,5 \%)$. Penelitian ini menunjukkan hasil serupa dengan penelitian yang dilakukan oleh Enany (2018) dimana pasien dengan oklusi vena retina kebanyakan usia tua lebih dari 50 tahun. ${ }^{5,7}$

Pada studi ini, seluruh pasien penelitian mengalami penurunan ketebalan makula sentral dalam satu bulan setelah injeksi intravitreal bevacizumab. Hal ini sejalan dengan studi oleh Enany (2018) yang juga memperlihatkan penurunan ketebalan makula sentral yang signifikan setelah injeksi intravitreal bevacizumab pasien dalam 3 bulan setelah onset. ${ }^{5}$

Penelitian oleh Mehany dkk (2010) didapatkan bahwa pasien dengan CRVO maupun BRVO menunjukkan perbaikan dengan injeksi intravitreal bevacizumab meskipun ada yang mengalami rekurensi dan membutuhkan injeksi ulang. ${ }^{7,15}$

Pada oklusi vena retina terdapat 2 mekanisme patogenesis edema makula sekunder yaitu Starling force dan peningkatan kadar VEGF. Pada oklusi vena retina terdapat peningkatan tekanan intravaskular dan transudasi plasma ke ruang ekstraaselular yang menyebabkan edema 
makula (Starling force). Oklusi vena retina juga menyebabkan hipoksia pada retina. Kadar VEGF sebagai faktor permeabilitas vaskular akan meningkat karena hipoksia. Perubahan ini menyebabkan VEGF akan diekskresikan ke retina sehingga meningkatkan permeabilitas vaskular yang memperburuk edema makula yang sebelumnya telah terjadi karena Starling force. Hal ini terjadi karena struktur arteriovena pada retina merupakan suatu system tertutup dengan sedikit pembuluh kolateral. Bila terjadi obstruksi pada vena akan menyebabkan iskemia retina. ${ }^{8,9}$

Untuk mengetahui ketebalan makula sentral dilakukan pemeriksaan OCT. Pemeriksaan Optical Coherence Tomography (OCT) adalah suatu pemeriksan diagnostik standar non-invasif untuk menggambarkan morfologi retina. OCT memberikan gambaran retina dengan resolusi tinggi, potongan melintang dan kuantitatif sehingga dapat mengukur ketebalan retina pada berbagai titik. Ketebalan makula sentral dapat diukur menggunakan OCT dan berhubungan dengan hasil pemeriksaan klinis dan fungsi visual. Secara keseluruhan rerata ketebalan makula (zona sentral $1 \mathrm{~mm}$ ) dengan SD-OCT adalah $241.75 \pm 17.3$ mikron. Studi lain menyatakan bahwa ketebalan fovea tidak melebihi 252 mikron pada mata yang normal. Ketebalan makula paling tipis pada bagian sentral dan paling tebal dalam diameter $3 \mathrm{~mm}$ dari sentral dan semakin berkurang ke arah perifer makula. Kuadran temporal lebih tipis dari kuadran nasal. Kuadran superior dan nasal merupakan yang paling tebal di antara kuadaran lainnya. Penelitian oleh Adhi dkk menunjukkan rerata ketebalan makula sentral pada subjek penelitiannya adalah 262, 86 $\mu \mathrm{m} .^{11-13}$

Prinsip utama penanganan CRVO adalah mengembalikan perfusi jaringan retina, mengatasi faktor predisposisi dan mencegah komplikasi lebih lanjut berupa edema makula kronik dan sikatrik pada makula.
Secara umum penatalaksanaan pada CRVO adalah dengan terapi medik dan terapi bedah. Terapi medik dengan cara mengurangi faktor-faktor resiko seperti mengatasi hipertensi, hiperlipidemia, pemberian antikoagulan (contoh: heparin); mengurangi viskositas darah (hemodilusi), penggunaan steroid (sistemik atau intravitreal), dan pemberian anti VEGF intravitreal. Penyuntikan Bevacizumab intravitreal dapat dilakukan dengan dosis 1-1,25 mg yang dapat diulang dengan jarak interval 6 minggu. ${ }^{2-4,6}$

\section{Vascular Endothelial Growth Factor} (VEGF) memiliki peranan dalam patologi sistem vaskuler melalui permeabilitas berlebihan ataupun neovaskularisasi abnormal. Keberhasilan dalam menghambat kerja abnormal VEGF dapat mencegah kerusakan retina. Anti-VEGF adalah zat yang diproduksi diluar tubuh yang kerjanya spesifik menghambat kerja abnormal VEGF. Anti-VEGF bekerja dalam 3 cara, yaitu penghambatan intra seluler, penghambatan ekstra seluler dan penghambatan sinyal sel target VEGF. ${ }^{2-4,6}$

Pasien dengan CRVO memiliki resiko neovaskularisasi retina, dimana keadaan iskemik pada retina akan menyebabkan keadaan hipoksia yang akan menginduksi sekresi VEGF dan menyebabkan terjadinya neovaskularisasi. Beberapa penelitian menunjukkan anti-VEGF intravitreal seperti bevacizumab efektif dalam mengobati pasien dengan CRVO terutama dalam mengurangi edema makula dan memperbaiki ketajaman penglihatan. ${ }^{2-4,6}$

Antibodi anti-VEGF bevacizumab merupakan antibody monoclonal yang berikatan dengan seluruh isoform VEGF-A. Bevacizumab menghambat ikatan VEGF dengan reseptornya sehingga permeabilitas kapiler dapat dipertahankan dan edema makula dapat berkurang. Penggunaan injeksi intravitreal obat anti-VEGF bertujuan untuk mengurangi aktivitas VEGF dimana oklusi 
vaskular menginduksi peningkatan kadar VEGF yang menyebabkan peningkatan permeabilitas vaskular dan menimbulkan edema makula. Studi klinis terbaru melaporkan adanya keuntungan dalam penggunaan anti-VEGF sebagai terapi edema makula karena BRVO. ${ }^{7-9,11-14,16,17}$

Bevacizumab (Avastin ${ }^{\circledR}$, F. Hoffmann-La Roche Ltd) yang merupakan antibodi monoklonal yang juga mengikat seluruh bentuk VEGF-A telah digunakan luas secara off-label sebagai tatalaksana edema makula sekunder oleh BRVO dan CRVO, seperti halnya pada diabetik makula edema dan AMD neovaskular. Pada beberapa studi percobaan didapatkan bahwa bevacizumab intravitreal dapat memperbaiki tajam penglihatan dan menurunkan ketebalan fovea sentral pada edema makula yang berhubungan dengan BRVO., ${ }^{5,15}$

Meskipun terjadi perbaikan signifikan pada edema makula sekunder akibat BRVO yang terjadi setelah injeksi intravitreal bevacizumab, protokol penatalaksanaan yang optimal masih belum diketahui dengan jelas. Untuk mencapai respon terapeutik maksimal, injeksi bevacizumab mungkin saja tidak harus diberikan setiap bulan. ${ }^{7}$

Proses penyembuhan segera dari morfologi makula yang fisiologis secara potensial mengurangi kerusakan fungsi retina akibat edema makula yang persisten maupun berulang dan dapat meningkatkan perbaikan fungsi penglihatan. Pada sebuah studi dikatakan bahwa edema makula dapat berulang dalam 3 bulan setelah injeksi intravitreal bevacizumab yang pertama dengan jadwal injeksi ulang sesuai kebutuhan. Hal ini menyebabkan perlunya 3 kali injeksi tiap bulan pada fase induksi agar dapat memperbaiki luaran perbaikan tajam penglihatan selanjutnya. ${ }^{7}$

Pada kasus BRVO dapat terjadi resolusi spontan setelah beberapa saat. Bila BRVO tidak mengalami resolusi maka dapat diberikan terapi inisial dengan anti-VEGF bevacizumab. Pada pasien dengan edema makula, injeksi intravitreal bevacizumab $(0,05 \mathrm{ml} / 1,25 \mathrm{mg}) \mathrm{ke}$ dalam rongga vitreus melalui pars plana telah menunjukkan hasil yang efektif bagi perbaikan edema dan perbaikan tajam penglihatan. Injeksi bevacizumab setiap 6 minggu selama 6 bulan dapat memperbaiki tajam penglihatan dan secara signifikan megurangi edema. ${ }^{15-17}$

Pikkel dkk membandingkan efek protokol injeksi bevacizumab yang diberikan satu kali dimulai dalam satu bulan pertama kejadian CRVO versus mulai pemberian terapi setelah 3 bulan dari kejadian. Hasil studi menunjukkan bahwa waktu pemberian memiliki efek yang besar dibadingkan dengan jumlah pemberian injeksi itu sendiri. Pasien yang mendapat satu kali injeksi bevacizumab di awal dalam satu bulan kejadian CRVO menunjukkan perbaikan tajam penglihatan final yang lebih baik dibanding pasien yang mendapat tiga kali injeksi namun dengan injeksi pertama yang diberikan lebih dari dua bulan setelah kejadian CRVO. $^{15}$

Kriechbaum dkk melaporkan makula yang lebih kering setelah satu kali injeksi (80\%) walaupun $45 \%$ dari pasien membutuhkan lebih dari satu kali injeksi bevacizumab. Kreutzer dkk melaporkan rerata ketebalan retina berkurang dari $474 \mu \mathrm{m}$ menjadi 316 $\mu \mathrm{m}$ pada 6 bulan setelah injeksi intravitreal bevacizumab 1,25 mg. 5,16

\section{KESIMPULAN DAN SARAN}

Pada penelitian ini didapatkan kesimpulan bahwa semua pasien mengalami penurunan ketebalan makula sentral 1 bulan pasca injeksi intravitreal bevacizumab yaitu sebanyak 8 subjek (100\%). Pengukuran ketebalan makula sentral sebelum dan sesudah injeksi dilakukan setidaknya satu bulan pasca injeksi intravitreal bevacizumab untuk dapat melihat perubahan kondisi makula. Penelitian deskriptif ini memiliki 
beberapa kelemahan penelitian yaitu jumlah sampel yang sedikit, subjek yang tidak dirandomisasi, serta waktu follow up yang tidak seragam. Diperlukan penelitian lanjutan dengan metodologi penelitian yang berbeda dan jumlah sampel yang sesuai.

\section{Daftar Pustaka}

[1] Doguizi, Sibel, et al. Case report: A rare Cause of Unilateral Central Retinal Vein occlusion in a Young Pasient: Type III Mixed Cryoglobulinemia. Ophthalmological Medicine; 2016. 2016. pp:1-4.

[2] Pichi, Fransisco, et al. Central Retinal Vein Occlusion. American Academy of Ophtahlmology. United States. 2016.

[3] Patel, Amy. Central retinal Vein Occlusion: A Review of Current Evidence-based Treatment Option. Midle East African Journal of Ophthalmology; 23(1). 2016. pp:44-48.

[4] Noma, Hidetaka. Clinical Diagnosis in Central Retinal Vein Occlusion. J Med Diagn Meth; 2(2). 2013. pp:1-4.

[5] Enany H. Evaluation of early versus late intravitreal bevacizumab injection in the treatment of macular edema secondary to branch retinal vein occlusion. Delta Journal of Ophthalmology; 19(1). 2018. pp:58-64.

[6] Hikichi T, et al. Two-year outcomes of intravitreal bevacizumab therapy for macular oedema secondary to branch retinal vein occlusion. Br J Ophthalmo; 98. 2014. pp:195199.

[7] Kartasasmita A, Takarai S, Switania A et al. Efficacy of single bevacizumab injection as adjuvant therapy to laser photocoagulation in macular edema secondary to branch retinal vein occlusion. Clinical Ophthalmology; 10. 2016. pp:2135-2140.

[8] Campochiaro PA, Bhisitkul RB, Shapiro H, Rubio RG. Vascular endothelial growth factor promotes progressive retinal nonperfusion in patients with retinal vein occlusion. Ophthalmology; 120(4). 2013. pp:795-802.

[9] Yuan A, Ahmad B, Xu D et al. Comparison of intravitreal ranibizumab and bevacizumab for the treatment of macular edema secondary to retinal vein occlusion. Int $J$ Ophthalmol; 7(1). 2014. pp:86-91.

[10] Agarwal P, Saini VK, Gupta S et al. Evaluation of Central Macular Thickness and Retinal Nerve Fiber Layer Thickness using Spectral Domain Optical Coherence Tomography in a Tertiary Care Hospital. J Curr Glaucoma Pract; 8(2). 2014. pp:75-81.

[11] Chan A, Duker J, Ko T. Normal Macular Thickness Measurements in Healthy Eyes Using
Stratus Optical Coherence Tomography. Arch Ophthalmol; 124(2). 2006. pp:193-198.

[12] Adhi M, Aziz S, Muhammad K et al. Macular Thickness by Age and Gender in Healthy Eyes Using Spectral Domain Optical Coherence Tomography. PLoS ONE; 7(5). 2012. pp:37-38.

[13] Ehlers J, Kim S, Yeh S. Therapies for Macular Edema Associated with Branch Retinal Vein Occlusion. Ophthalmology ; 124. 2017. pp:14121423.

[14] Mehany S, Mourad K, Shawkat A et al. Early Avastin management in acute retinal vein occlusion. Saudi Journal of Ophthalmology; 24. 2010. pp:87-94.

[15] Kriechbaum K, Michels S, Prager F et al. Intravitreal Avastin for macular oedema secondary to retinal vein occlusion: a prospective study. Br. J. Ophthalmol; 92(4). 2008. pp:443.

[16] Adjievska B, Boskurt S, Orovcanec N et al. The outcome of low-frequency intravitreal bevacizumab therapy for macular edema in retinal vein occlusions. Clinical Ophthalmology; 11. 2017. pp:1183-1190. 